\title{
The Effect of Textual Metafunction on the Iranian EFL Learners' Writing Performance
}

\author{
Mandana Eftekhar Paziraie ${ }^{1}$ \\ ${ }^{1}$ Department of English, Faculty of Foreign Languages, Central Tehran Branch, Islamic Azad University, Iran \\ Correspondence: Mandana Eftekhar Paziraie, Department of English, Faculty of Foreign Languages, Central \\ Tehran Branch, Islamic Azad University, Tehran, Iran. Tel: 98-919-127-8140. E-mail: meftekharp@gmail.com
}

Received: November 26, 2012 Accepted: December 19, 2012 Online Published: December 26, 2012

doi:10.5539/elt.v6n2p71 URL: http://dx.doi.org/10.5539/elt.v6n2p71

\begin{abstract}
This study is devoted to the effect of 'textual metafunction' on the levels of coherence and cohesion in the Iranian EFL learners' English writing performance. Sixty Iranian intermediate EFL learners who were adult females participated in this study were randomly divided into two groups; experimental, and control. They were given a writing pre-test. Then both groups' subjects attended an essay writing class, two sessions per week, for a ten-week term; however, while the experimental group was taught how to write a standard three-paragraph essay in English, and apply the textual metafunction in it, the control group was only taught how to write a standard three-paragraph essay. After the completion of the instructional period, both groups were given a writing post-test in which they were asked to write a standard three-paragraph essay on a subject. The analytic scoring scale of 'Hungarian School-Leaving English Examination Reform' (2001, as cited in Tankó, 2001) was employed by three independent raters for rating the writing samples. A ' $t$-test' on the mean scores of both groups indicated a significant difference between the scores of the post-tests, meaning that the textual metafunction was significantly effective in the experimental group's writing task. Moreover, while the mean scores of the control group's pre-post tests were the same, the mean score of the experimental group's post-test was higher than that of the pre-test, meaning that textual metafunction increased the levels of cohesion and coherence in their writing task.
\end{abstract}

Keywords: coherence, cohesion, EFL learners, textual metafunction, writing performance, writing scale

\section{Introduction}

Many models of writing that have been developed since the 1970s and early 1980s (e.g. Bereiter \& Scardamalia (1987), Grabe \& Kaplan (1996), Flower \& Hayes (1980), Hayes (1996), Kellogg (1996) and Zimmerman (2000)) illustrate how written production is indeed a complicated process.

This cognitively demanding exercise can challenge those writing in L1, but for those writing in a foreign language, the challenges are even greater. Flower and Hayes (1980, as cited in Manchón, 2009) emphasized on the importance of writing and developed the processes in which the expert writers engage. These processes include the three broad stages of planning, formulating, and revising. Kroll (2008: 230-231) also, emphasized on the importance of writing skill and believed that the school essay is one of the most frequent forms of writing. According to Kroll "it is used in matriculation examinations at the end of high school years, and large-scale tests of English proficiency, such as the TOEFL, now include an essay task." Craig (2013: 140), also mentioned to the significance of the writing skill; and believed that since the ESL/EFL learners are essentially depended on their teachers, and since the teachers are assigned many classes with many students, it is nearly impossible to teach all the necessary aspects of writing to students. The aspects of language needed to be concentrated in a writing task are high in number, and variable regarding the writing scales; however, since in the present study the main focus is on the coherence, and cohesion it is useful to illustrate the production and place of coherence, and cohesion in writing.

Cook (1989) states that there are two different kinds of language as the potential objects of study; one kind is the abstract form which is used to teach the language, the other kind, is used to communicate, and is known as the discourse. Therefore, discourse is the study of language in use. Furthermore, discourse analysis is the search for what gives it coherence. According to Halliday and Hasan (1976, as cited in Tanskanen, 2006) the interconnection of different parts of discourse in a context is called cohesion, and the interconnection of the 
cohesive parts is called coherence. In addition, there is a relationship between discourse, cohesion, and coherence (Eftekhar Paziraie, 2012a). In any special discourse, oral or written, cohesion and coherence should be united, so that the discourse has the chance to be created.

According to the above-mentioned facts, the significance of cohesion and coherence is not negligible, because these two elements create the discourse. In fact, a sound discourse is created when the sequence of the sentences is in a way in which all the grammatical and lexical elements and the relations between them are meaningful, purposeful, and interrelated. Therefore, it can be inferred that the sequence of sentences in a discourse is something different from the random sequence. Furthermore, according to Aijmer and Stenström (2004), the linguists have been focused on the principals of connectivity which bind a text together. In this regard, scholars such as Halliday and Hasan (1976), and Winter (1977), study the "clause relation", and believe that the clause is the unit of meaning. Halliday (1970) introduces a new approach to the linguistics named "Systemic Functional Grammar," in which he introduces three ideational, interpersonal, and textual metafunctions for language, and explains that coherence, and cohesion are created in a discourse through the textual metafunction. Since coherence, and cohesion are referred to as the study of meaning in language, and as Halliday (1970) believes these two factors are created through textual metafinction, it can be concluded that in different contexts including writing, the meaning can be achieved through the textual metafunction.

In this article the effect of textual metafunction in the Iranian EFL learners' writing tasks is going to be studied to see if it is possible to increase the level of coherence, and cohesion in their writing tasks through teaching it to the Iranian EFL learners.

There are various and sometimes different points of view about coherence and cohesion. However, there are some common themes among the scholars' viewpoints on this issue. Generally, the scholars believe that discourse is made up of cohesion and coherence, but what these two elements are, and how they are connected together is the issue of difference among them.

\subsection{What Is Coherence?}

"Etymologically, the word 'coherence' is derived from the Latin verb 'cohaeree' (to hang together)" (Redeker, 2004: 1, as cited in Al-Hajaj, \& Davis, 2008: 283). Al-Hajaj, and Davis (2008: 283), also analyze the definitions of coherence and believe that the traditional definitions mostly consider the product of writing rather than the process.

[...], the product of the process of writing, namely, a text, should hang together in a way that its content has some arrangement of order or sequence. Such an order or sequence is thought to be largely related to the connectedness between sentences or through using cohesive devices at the paragraph level. This view proves to be limited since it cannot explain obviously how to make the written text mainly to the use of cohesive devices.

In discourse analysis the term coherence is the extent to which a discourse is perceived to 'hang together' rather than being a set of unrelated sentences or utterances" (Martin and Ringham, 2006: 43).

Bickman (1987) also considers the traditional meaning in mind and believes that coherence is a quality of discourse. This definition as well is affected by the product side, i.e. the text, since Bickman knows coherence as a quality of a product named discourse. However, Oller and Jonz (1994: 25) believe that "Coherence is an abstract quality of the text (or discourse) supplied completely by the mind and with no necessary connection(s) to the world of experience." Similar to Bickman's definition, this definition also has a product-like look at coherence. Furthermore, Enkvist (1990) defines it as the quality, which makes a discourse adapt to a stable picture of the world of experiences. This definition seems to be more complete than the two earlier definitions in the sense that the last definition touches both the abstract and the concrete sides of coherence.

According to Bublitz, Lenk, and Ventola (1999), writing differs from face-to-face interaction in the way coherence is created. When in the written communication, coherence cannot be explicitly negotiated, in the oral communication it can be directed and explicitly discussed. It implies that while in an oral communication, the parties are not forced to express themselves clearly, in a written communication the writer needs to make the ideas, intentions, and arguments unmistakably clear. However, there's a significant question to be answered. What is coherence? And what aspect of language it is? In addition they believe that 'coherence' "comes out of the text" and it is not a text-oriented property, but it is based on "the language of the text, in the same way as it is based on additional information" (p. 2). Gernsbacher, and Givón (1995) believe that coherence is a mental activity. They state that it is not an inherent property of a written or spoken text. However, it is a property of what emerges during speech production and comprehension. In addition, they (1995: vii) conclude that "a coherently produced text-spoken or written- allows the "receiver" (listener or reader) to form roughly the same 
text-representation as the "sender" (writer or the speaker) had in mind".

\subsection{What Is Cohesion?}

Halliday and Hasan (1976: 4, as cited in Rubio 2007: 24) state that cohesion "occurs when the interpretation of some element in the discourse is dependent on that of another." According to this definition, Halliday and Hasan (1976, as cited in Eftekhar Paziraie, 2012b) introduce two main cohesive devices; grammatical and lexical. The grammatical cohesive devices are divided into four branches; "reference", "substitution", "ellipsis", and "conjunction." All these four types of grammatical cohesive devices show the combination of terms that form the grammatical aspect of the discourse. However, the lexical cohesive devices are divided into two branches of "collocation" and "reiteration." The lexical cohesive devices show the combination of terms that form the lexical aspect of the sentences. Generally, the grammatical and lexical cohesive devices make the sentences to stick together and be linked into larger units of paragraphs, stanzas, or chapters. Sanders and Maat (2006) summarize the grammatical and lexical cohesive devices as the following:

- Reference: two linguistic elements are related in what they refer to.

- Substitution: a linguistic element, which is not repeated but is replaced by a substitution item.

- Ellipsis: one of the identical linguistic elements, which is omitted.

- Conjunction: a semantic relation, which is explicitly marked.

- Lexical cohesion: two elements share a lexical field

De Beaugrande and Dressler (1981: 3-10, as cited in Tanskanen, 2006: 19) proposed a model in which cohesion "subsumes the procedures whereby the surface elements appear as progressive occurrences such that their sequential connectivity is maintained and made recoverable."

Cohesion is about how the sentences are created meaningfully. Therefore, it can be defined as one of the aspects of discourse.

\subsection{Systemic Functional Grammar ( $S F G$ )}

Sum-hung Li (2007: 10) notes that SFG (Systemic Functional Grammar) is inspired by the studies of psychologists, linguist, philosophers, and anthropologists such as de Sassure's distinction between the syntagmatic and paradigmatic axes; the Malinowski's notion of 'context of situation'; Firth's work on prosody and the concept of 'system'; to name a few. These concepts construct the theoretical context of SFG. According to Halliday (1985: 30 as cited in Sum-hung Li, 2007: 11) SFG is [...] an analysis-synthesis grammar based on the paradigmatic notion of choice... It is a tristratal construct of semantics (meaning), lexicogrammar (wording), and phonology (sound). The organizing concept at each stratum is the paradigmatic 'system... Options are realized as syntagmatic constructs of structures; a structure is a configuration of functional elements... A text is systemic-functional grammar is an instantiation of the system.

Similarly, Aghagolzadeh and Farazandeh-pour (2012) studied the theoretical basis of SFG and explained that the notion of systemic functional grammar was first raised by Halliday in the 1950s and 1960s, and then developed by other linguists such as Hasan, and Matthiessen. Martin (1992) applied the SFG to raise some questions about the structure of the text. Among all the theories proposed by different scholars, Aijmer, and Stenström $(2004: 8,9)$ know the Mann \& Thomsposon's theory of rhetorical relations (1988) as the most influential one in the computational domain and state that "text coherence is attributed to rhetorical relations such as contrast and sequence, which are mapped unto schemas rather than structures." Generally, it can be concluded that SFG sees language as the meaning-making resource with which people interact in various cultural and situational contexts (Eftekhar Paziraie, 2012a).

Correa (2008) introduces the two contexts of situation and culture, which are separated by the systemic functional linguists. According to Correa, these two contexts influence the students' writing tasks. While the context of culture refers to the purpose of the genre, the context of situation refers to the register in which the text is created (Eggins, 1994: as cited in Correa, 2008).

Halliday (1985) explains that all the written and oral discourses inherit three metafunctions; the ideational, interpersonal, and textual metafunctions. Then he defines each of these three metafunctions and elaborates their roles in a discourse. As Halliday (1970: 143) defines, "the ideational metafunction is concerned with the speaker's experience of the real world." The interpersonal metafunction "serves to establish and maintain social relations", and the textual metafunction "enables the speaker or writer to construct texts." one significant point about logical metafunction is that it is divided into two subcategories: the 'experiential' and the 'logical'. Having Halliday's definition of the textual metafunction in mind, it can be stated that it is focused on creating coherence 
and cohesion in texts. This point has also been mentioned by other scholars such as Dias, Freedman, Medway, and Par (2008: 136), who believe that "a textual metafunction is about achieving a coherent verbal construct."

Ghadessy (1995: 20-22) describes the way in which the meaning is created and postulates that the experiences of the physical, biological, and social phenomena can be interpreted as meaning. Thus according to him, meaning can be created through the ideational and interpersonal metafunctions; however, he knows meaning something beyond the physical, biological, and social phenomena. Therefore, he states that "the textual metafunction constructs ideational and interpersonal meanings as information that can be shared by speaker and addressee; and it enables this sharing by providing the resources for guiding the exchange of meaning in text." (p. 22).

\subsection{Textual Metafunction}

Taboada (2004) explains the textual metafunction is the one in which language as a discourse is organized to function as a complete message. Taboada, then explains that the Theme is the departure point of the message, and the Rheme is the part in which the Theme is developed.

Caffarel, Martin, and Matthiessen (2004) claim that the speakers (writers) are able to use the textual resources to organize the production of text, and guide the listeners (readers) in the process of interpreting the text. Therefore, they believe that these resources "are the units organized to guide the process of creating and interpreting text." (p. 635). Furthermore, they explain the potential dimensions of the textual metafunction as the "(i) thematicity, (ii) newsworthiness, (iii) specificity." (p. 637). According to them, the subjects can be thematic, given, and specific; whereas complements can be non-thematic, new, and non-specific.

Fries and Gregory (1995: 48-50) also study the structure of textual metafunction and postulate that the textual metafunction focuses on the process of information in a text;

The information structure divides the information being conveyed into messageable chunks and imposes structures such as Given and New. New information is information the speaker has coded as not recoverable from the context. The other structure imposed by the textual function, the thematic structure, imposes the structures Theme and Rheme on the clause. (p. 48)

Also, these two scholars scrutinize the Theme in one simple clauses, and conclude that it comes at the beginning, in the combination of hypotactically related clauses, in which they believe the subordinate clause is the theme, on the condition that it comes first, and if the superordinate clause comes first, then it will be the theme, as well as, in the sentences consist of two or more complete independent clauses that are paratactically related, in which the complex clause will be served as two or more clause complexes. Therefore, as they believe it is possible to link thematic content to some aspect of the meanings of texts.

Christie and Derewianka (2010: 20) define the Theme as a cue to the reader, "This is what I'm talking about." Moreover, they define Rheme as the provider of the new information.

Eggins (2004) believes that without the textual metafunction, the experiential and interpersonal meanings cannot be expressed in a coherent manner. She also analyzes the structure of theme as one of the two constituent elements of the textual metafunction in detail, and postulates that Theme is divided into the two Marked and Unmarked branches. While the unmarked reminds us the usual theme, the marked theme, reminds the unusual theme. She explains that the unmarked theme is achieved when the element, which is theme, is also playing the role of a subject (in a declarative clause), finite (in an interrogative), predicator (in an imperative), or a WH element (in a WH-interrogative); however, the marked theme is when the theme is combined with any other element from the Mood system. "The commonest type of the marked Theme is Theme conflating with an Adjunct: circumstantial (which is not conflated with a WH element)" (p. 318). According to this categorization, she concludes that the "skillful writers and speakers choose marked Themes to add coherence and emphasis to their text." (p. 320)

\subsection{The Writing Process}

Brown and Hood (2003: 6) state that the writing process depends on different factors: who you are writing to (the reader), why you are writing (purpose), what you are writing about (content), where you are, how much time you have, how you feel, etc. (situation). Furthermore, they introduce and explain the three stages of preparing to write, while you are managing the time and skill to write, drafting, while one is beginning to write, and revising, while you compare what you wanted to say, with what you have said, to check if you really said everything you were determined to say. However, Atlee (1995) believes that there are five stages in each writing process, including prewriting, composing, revising, editing, and publishing.

Sundem (2007) talks about the purposeful program for writing and points out that any teacher or instructor needs 
to provide their students with a chart so that they are informed about the daily writing activities. In order to make it clear, he presents a sample of the Daily Information Board. This chart includes 4 sections of Introduction, Mini Lesson, Independent writing, and sharing/wrap-up, respectively, each of which includes some explanations.

\begin{tabular}{lll} 
Introduction & Authentic spelling: Test words/ create new note cards \\
\hline Mini Lesson & Preview Author's Chair producers \\
\hline Independent Writing & Class & Teacher \\
\hline & $\begin{array}{l}\text { Finish incorporating revision ideas, proofreading, } \\
\text { publishing, and any outstanding activity sheets. }\end{array}$ & $\begin{array}{l}\text { editors; distribute appropriate } \\
\text { Peer/ Adult Critique sheets. }\end{array}$ \\
\hline
\end{tabular}

Sharing/ Wrap-up Share a couple of Author's Chairs.

\subsection{Writing Assessment and Writing Scales}

Until 1950s, the direct writing assessment method allowed the individual teachers to rate the writing performances in the context of their classes; however, due to an increase in the number of university enrollments, the indirect writing assessment was developed (Grabe, \& Kaplan, 1996, as cited in Knoch, 2009). In the indirect method, the students' knowledge of writing is assessed by applying the discrete test items of particular linguistic features. (Knoch, 2009). After that in the late 70s and early 80s, the direct writing assessment became the standard practice in English L1 contexts. However, in the late 80s, this model was criticized broadly, and since then the writing assessment was based on the form in which the students were asked to write a brief (30-40 min) essay, which is then rated either holistically or analytically by trained raters using a rating skill (Cumming, 1997, as cited in Knoch, 2009). In the furtherance of the discussion, Knoch introduces some of the major standardized writing assessments around the world, naming the IELTS, and TOEFL iBT, and explains the differences and similarities between these two writing tests. As Knoch explains, in the first one, there are two writing tasks, which are rated only by one trained rater; while in the second one, which also includes two writing tasks, there are two trained raters, and a third in a case of discrepancies).

Weigle (2002: 109, as cited in Shaw and Weir 2007: 149) examine and declare the three main types of rating scales: primary trait scales, holistic scales, and analytic scales. The three scales:

Can be characterized by two distinctive features: (1) whether scale is intended to be specific to a single writing task or generalized to a class of tasks (broadly or narrowly defined), and (2) whether a single score or multiple scores are given to each script.

Besides, there are some differences among the above scales; while the primary trait scale is specific to an individual writing task, the holistic and analytical scales have indeed been accepted in teaching practices more generally, and more specifically in second language testing (Canale, 1981, Carroll, 1980, Jacobs et al, 1981, Perkins, 1983, as cited in Shaw and Weir, 2007).

However, Cooper and Odell (1977: 4, as cited in Speck \& Greenwood, 1998: 237) define the holistic evaluation as "any procedure which stops short of enumerating linguistic, rhetorical, or informational features of a piece of writing." Moreover, they introduce seven types of holistic evaluation: essay scale, analytic scale, dichotomous scale, feature analysis, primary trait scoring, general impression marking, and center of gravity response. Therefore, contrary to the Wiegle's categorization, Cooper and Odell know the holistic evaluation as the umbrella scale and the other forms as the branches of this general scale.

\subsection{Major Research Projects Done on the Writing Skill}

In a study Hawkey and Barker (2004), analyzed the results of the writing tasks of the three Cambridge ESOL examinations including; FCE, CAE, and CPE, through a computer-based and an intuitive approaches to find a common writing scale. Based on the results achieved from the study, the writers developed a draft of a new analytical writing scale based on three criteria; sophistication of language, organization and links, and accuracy.

Yet, in another study Barkaoui (2007) applied a mixed method approach to investigate the effects of two different writing scales on EFL essay scores; rating processes, and raters' perceptions, through thinking aloud, and silent protocols. In order to do that, Barkaoui asked the 4 raters to rate and score the 32 students' essays once through the EFL Placement Test seven-level scale developed by Tyndall and Kenyon (1996, as cited in Barkaoui, 2007), and then through the Composition Grading Scale developed by Brown and Bailey (1984) as the holistic 
and multiple-trait rating scales, respectively. In order to analyze the data, he used the G-theory, and found out that the holistic scale had higher inter-reliability agreement, than that of the multiple-trait.

Furthermore, in another study, Ahour and Mukundan (2009), studied the effect of one writing component to the variance of overall writing performance. In order to do that they applied Weir's model (1990) of analytical writing scale, including, cohesion, vocabulary, grammar, and organization, and analyzed the 128 students' writing samples, which were rated by two separate raters. The results showed that while the grammar had the highest contribution to the variance of the total writing skill, the component of the organization had the lowest amount. Furthermore, the results showed that the students' weaknesses were mostly in the cohesion and grammar components.

In addition, in another study, Campos (2010) compared the two different holistic and analytic writing rubrics and explained the condition necessary to use each one. As Campos believes, the holistic rubric does not list the levels of performance separately; therefore, it is used when general judgments are needed to be made. However, according to Muller (2010, as cited in Campos, 2010) the analytic rubric provides detailed information for each level of performance and then combines them to get an overall total.

The present study attempted to answer the question: "how effective is the use of textual metafunction in improving the writing skill through increasing the levels of cohesion and coherence in the adult EFL learners?" In the light of reviewing the most related literature, the present study was concerned with testing the following null hypothesis:

1. There would be no significant difference between the effect of 'textual metafunction' on the Iranian EFL learners' writing performance.

\section{Method}

\subsection{Participants}

Sixty Iranian female adult intermediate EFL learners who were selected from seventy-six students studying at an English institute in West of Tehran, Iran served as the participants of the present study. The selection was based on the scores they obtained on the ELPE (English Language Proficiency Exam). Their ages ranged from twenty to thirty-five years old. They were exposed to English as a foreign language for at least 6 years before being accepted at this level.

\subsection{Research Design}

To see what effects the textual metafunction may have on the levels of cohesion and coherence in the Iranian EFL writing tasks, a true-experimental design was employed, contrasting the performance of the experimental and control groups on the use of textual metafunction in pre-post-tests. This design enables the researcher to study the effect of textual metafunction before and after the instructional period on two experimental and control groups. Therefore, the results achieved would be reliable.

\subsection{Rating Scale}

The analytic scoring scale of Hungarian School-Leaving English Examination Reform (2001, as cited in Tankó, 2001: 127) was employed by three raters to evaluate the participants' writing samples. This scale puts emphasis on four components of writing including text achievement, coherence and cohesion, grammar, and vocabulary, each of which is scored from 0-7 (See Appendix). The reliability of this scale has been checked in this study and the high Cronbach's Alpha (0.83) was obtained.

\subsection{Data Collection}

The researcher used four data collection instruments: the ELPE, the pre-test, the suggested training model, and the post-test.

\subsubsection{The ELPE}

The instrument for homogenizing the participants was a sample ELPE to ensure that the participants of the study had almost the same general proficiency level. Therefore, at the first step, the sample ELPE, which was about to be used in the present study had to be piloted for assuring of the reliability of the test. In order to do so, the researcher administered a sample ELPE to a group of 34 intermediate students who were not the main participants of this study, demonstrating similar characteristics as the target sample. The ELPE composed of six sections including the interview, writing, listening, reading, vocabulary, and grammar. The maximum score on the test was eighty points. The time allotted for responding to the questions of the test was three hours and ten minutes. All items went through an item analysis procedure, and item facility, item discrimination of the test and 
the reliability of test was calculated which was equal to 0.92 , on the basis of which no item was discarded and they all enjoyed acceptable indices. The researcher used the piloted test as an instrument for homogenizing the participants of the study. The standard general ELPE was administered among 76 intermediate learners, who were placed at the mentioned level according to the placement of the English Institute. Then, 60 participants whose score fell within the range of one standard deviation above and below the mean on the ELPE was chosen to participate in the study.

\subsubsection{The Pre-test}

When the ELPE was conducted and 60 participants were chosen, the researcher divided the 60 participants randomly into two experimental and control groups (EG, \& CG). Then, a writing pre-test was conducted and the participants were asked to write a standard three-paragraph essay on a specific subject (describe your favorite English teacher) in 45 minutes. Three raters rated the writing samples by the use of Hungarian analytical rating scale (2001, as cited in Tankó, 2001: 127) where the scores ranged from 0-7.

\subsubsection{The Suggested Training Model}

During the instructional period, the participants of the EG, attended an essay writing class, two sessions per week, for a ten-week term during which they were given a pamphlet titled "The Metafunctions and Their Applications." This pamphlet was composed of three chapters; each chapter was up to 60 pages. The first chapter was allotted to the introduction of metafunction and the theoretician. The second chapter was composed of three sections; each section was allotted to the explanation of one of the metafunctions and the components. However, since this study was focused mainly on the application of the "Textual Metafunction," this section was only taught to the participants. It is worth mentioning that this section was divided into three subsections; Textual Metafunction and Components, Cohesion and Coherence. Finally, the last chapter was allotted to 'Writing'. In the last chapter, the participants were taught how to write a standard three-paragraph essay in English. It also should be noted that at the end of each chapter, and section, some exercises were considered for the participants so that they had a chance to check their understanding of the study. As an example, at the end of chapter one, the participants were asked some comprehension questions about the metafunctions. At the end of chapter 2, section 3, which was all about the Textual Metafunction, there were some sentences, and the participants were asked to underline the Theme and Rheme in each sentence. Furthermore, they were given some writing samples, some sentences in which were not cohesive and coherent, and the participants were asked to change them to coherent and cohesive sentences. Finally, at the end of the chapter three, the participants were asked to write a three-paragraph essay on a selected topic as a homework assignment. The other group, namely the control group (CG), passed the same stages, with the difference that they were given a pamphlet which was composed of one chapter; How To Write a Three-Paragraph Essay in English. This chapter and the exercises were completely similar to the second chapter of the EG's pamphlet.

\subsubsection{The Post-test}

Finally at the end of the instructional period, the writing post-test was administered to both groups to investigate the effect of 'textual metafunction' on the levels of cohesion and coherence in the EFL learners' English writing performance. In the post-test the participants of both groups were asked to write a standard three-paragraph essay (including, introduction, development, and conclusion parts) on the subject; "describe your favorite summer vacation" in fifty minutes. Then the essays were evaluated by the three raters; the researcher herself, and two of her colleagues by the use of the Hungarian analytical rating scale (2001, as cited in Tankó, 2001: 127), where the scores ranged from $0-7$.

Finally, in order to analyze the data, the writer used the independent "t-test," in which she compared the means of EG, with the means of CG, to find the final result, and to see if the textual metafunction can make significant changes in the coherence and cohesion levels of the essays.

\section{Results}

At the beginning, the participants of EG, and CG were given a writing pre-test, to make sure that they are at the same level of writing skill. In order to compare the means on the pre-test, the 'independent t-test' was used, the results of which is shown in table 1 . 
Table 1. The Results of the Independent Samples t-test for the Mean Rating on Writing Pre-Test

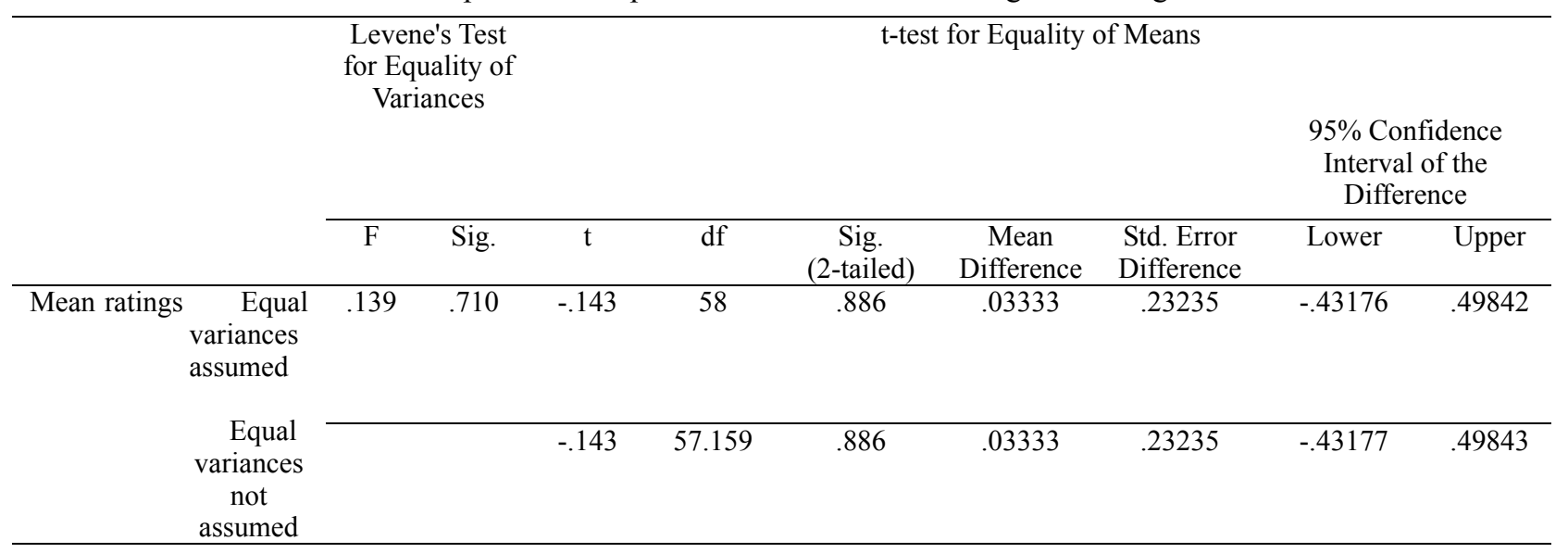

As shown in table 1 , there is no significant difference between variances of the two groups $((\mathrm{F}=0.139, \mathrm{p}=$ $0.886>0.05$ ). In addition, the difference between the mean scores of the two groups is not statistically significant $(t=0.143, p=0.886,>0.05)$. That is, the results of the $t$-test showed that there was no significant difference between the mean scores of two groups ( 0.3333 and 0.3333$)$.

To test the hypothesis, "There would be no significant difference between the effect of 'textual metafunction' on the Iranian EFL learners' writing performance." the two groups' post-test essays were evaluated based on the analytical writing scale developed by Hungarian School-Leaving English Examination Reform Project (2001). However, as it was stated earlier, since the main focus here is on cohesion and coherence, these factors among the other factors were only evaluated in the participants' essays. In order to compare the means the 'independent t-test' was used (table 5).

\subsection{The Results of the Experimental Group's Writing Post-test}

The performance of the EG participants on the writing post-test was rated by three raters, and inter-rater reliability was estimated (Table 1 ).

Table 2. Inter-rater Consistency on the Experimental Group's Writing Post-test

\section{Correlations}

\begin{tabular}{|c|c|c|c|c|}
\hline & & Rater 1 & Rater 2 & Rater 3 \\
\hline Rater 1 & Pearson & & & \\
\hline Correlation & $\mathrm{Sig}$ & 1 & $.708^{* *}$ & $\begin{array}{l}.896^{* * *} \\
000\end{array}$ \\
\hline (2-tailed) & & 30 & & \\
\hline Rater 2 & & & & \\
\hline Correlation & & $.708 * *$ & 1 & $.787 * *$ \\
\hline (2-tailed) & Sig. & $\begin{array}{l}.000 \\
30\end{array}$ & & $\begin{array}{l}.000 \\
30\end{array}$ \\
\hline $\begin{array}{l}\text { Rater 3 } \\
\text { Correlation }\end{array}$ & & $.896 * *$ & & 1 \\
\hline (2-tailed) & $\begin{array}{l}\text { Sig. } \\
\text { N }\end{array}$ & $\begin{array}{l}.000 \\
30\end{array}$ & $\begin{array}{l}.000 \\
30\end{array}$ & 30 \\
\hline
\end{tabular}

**. Correlation is significant at the 0.01 level (2-tailed).

As Table 2 demonstrates, the correlation between the ratings of the three raters, i.e. the researcher herself and two of her colleagues in the institute is high, i.e. the correlation between the ratings of the first and second rater is 0.7 , the correlation between the first and the third rater is 0.8 , and the correlation between the second and the third rater is also 0.7 .

\subsection{The Results of the Control Group's Writing Post-test}

The performance of the EG participants on the writing post-test was rated by three raters, and inter-rater reliability was estimated (Table 2). 
Table 3. The Inter-rater Consistency on the Control Group's Writing Post-Test

\section{Correlations}

\begin{tabular}{|c|c|c|c|c|}
\hline & & Rater 1 & Rater 2 & Rater 3 \\
\hline \multirow{2}{*}{$\begin{array}{l}\text { Rater } 1 \\
\text { Correlation }\end{array}$} & Pearson & 1 & $.866^{* *}$ & $.833 * *$ \\
\hline & Sig. (2-tailed) ${ }_{\mathrm{N}}$ & 30 & $\begin{array}{l}.000 \\
30\end{array}$ & $\begin{array}{l}.000 \\
30\end{array}$ \\
\hline \multirow{3}{*}{$\begin{array}{l}\text { Rater } 2 \\
\text { Correlation }\end{array}$} & Pearson & $866 * *$ & 1 & $828 * *$ \\
\hline & $\operatorname{Sig}$ (2-tailed) & .000 & & \\
\hline & ${ }_{\mathrm{N}}^{\mathrm{Sig} .(2 \text {-talled) }} \mathrm{N}$ & 30 & 30 & 30 \\
\hline \multirow{2}{*}{$\begin{array}{l}\text { Rater 3 } \\
\text { Correlation }\end{array}$} & Pearson & $.833^{* *}$ & $.828^{* *}$ & 1 \\
\hline & Sig. (2-tailed) & $\begin{array}{l}.000 \\
30\end{array}$ & $\begin{array}{l}.000 \\
30\end{array}$ & 30 \\
\hline
\end{tabular}

**. Correlation is significant at the 0.01 level (2-tailed).

As Table 3 demonstrates the correlation between the ratings of the three raters was equal to 0.8 , meaning that there was a high correlation between the ratings of the raters. It is worth mentioning that the Pearson correlation is a parametric test and requires checking the normality of the distribution scores.

Table 4. Descriptive Statistics for the Both Groups' Writing Post-Test Mean Ratings

\begin{tabular}{lc}
\multicolumn{2}{c}{ Mean Ratings } \\
\hline $\mathrm{N}$ & 30 \\
Valid & 0 \\
& 4.7667 \\
Missing & 0.16531 \\
Mean & 1.28045 \\
Std. Error of Mean & \\
Std. Deviation & \\
\hline
\end{tabular}

\subsection{Testing the Null Hypothesis}

In order to be able to test the hypothesis of the study, which stated that "There would be no significant difference between the effect of 'textual metafunction' on the Iranian EFL learners' writing performance," the mean scores of the EG, and CG were to be compared; therefore, the 't-test' was used.

However, in order to be able to legitimately run the t-test, the researcher needed to check the normality of the distribution scores. Table 4 demonstrates the descriptive statistics for the two groups' writing post-tests and the computation of the degree of skewness by the standard error of skewness (table 5), in which 'EGPT' stands for Experimental Group Post-Test, and 'CGPT' stands for Control Group Post-Test.

Table 5. Results of Checking the Normality of the Distributions of the Two Groups' Writing Post-Test scores

\begin{tabular}{cccccc}
\hline Mean & $\begin{array}{c}\text { Standard } \\
\text { Deviation }\end{array}$ & skewness & $\begin{array}{c}\text { Standard error of } \\
\text { skewness }\end{array}$ & Ratio \\
\hline EGPT & 5.73 & .785 & .524 & .427 & 1.22 \\
\hline CGPT & 3.80 & .887 & .420 & .427 & 0.98 \\
\hline
\end{tabular}

As it is shown in table 5, the results for both distributions came out to be between -1.96 and +1.96 , thus the scores of both groups' writing post-tests were normally distributed. Therefore, the researcher could legitimately run an independent ' $t$-test' (Table 6). 
Table 6. The Results of the Independent Samples t-test for the Mean Rating on Writing Post-Test

\begin{tabular}{|c|c|c|c|c|c|c|c|c|c|c|}
\hline & \multirow{2}{*}{\multicolumn{2}{|c|}{$\begin{array}{l}\text { Levene's Test } \\
\text { for Equality of } \\
\text { Variances }\end{array}$}} & \multicolumn{7}{|c|}{ t-test for Equality of Means } \\
\hline & & & & & & & & & \multicolumn{2}{|c|}{$\begin{array}{l}95 \% \text { Confidence } \\
\text { Interval of the } \\
\text { Difference }\end{array}$} \\
\hline & & $\mathrm{F}$ & Sig. & $\mathrm{t}$ & df & $\begin{array}{l}\text { Sig. } \\
\text { (2-tail } \\
\text { ed) }\end{array}$ & $\begin{array}{c}\text { Mean } \\
\text { Difference }\end{array}$ & $\begin{array}{l}\text { Std. Error } \\
\text { Difference }\end{array}$ & Lower & Upper \\
\hline \multirow[t]{2}{*}{ Mean ratings } & $\begin{array}{l}\text { Equal } \\
\text { variances } \\
\text { assumed }\end{array}$ & 1.567 & .216 & 8.942 & 58 & .000 & 1.93333 & .21620 & 1.50056 & 2.36611 \\
\hline & $\begin{array}{c}\text { Equal } \\
\text { variances } \\
\text { not } \\
\text { assumed }\end{array}$ & & & 8.942 & 57.159 & .000 & 1.93333 & .21620 & 1.50042 & 2.36624 \\
\hline
\end{tabular}

According to table 5, there was a significant difference between variances of the two groups $(\mathrm{F}=1.567$, $\mathrm{p}=0.0001<0.05$ ). In addition the difference between the means of the scores of the two groups is statistically significant $(t=8.942, \mathrm{p}=0.0001<0.05)$. That is the results of the $\mathrm{t}$-test showed that there was a significance difference between the mean scores of two groups (5.73, and 3.80). Therefore, the researcher concluded that using the textual metafunction is useful in cohesion and coherence on the writing performance of the participants. Figure1, depicts visually the difference between the means of the two groups' post-tests.

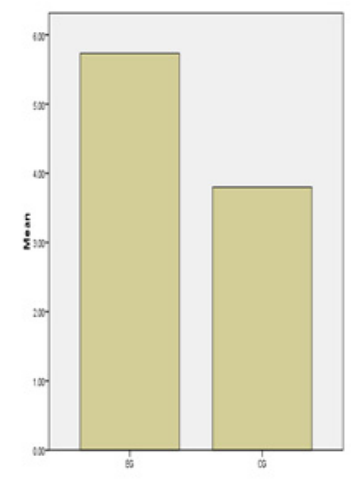

Figure 1. Bar Graph Representing the Mean Difference between the Two Groups

\section{Conclusion and Recommendations}

The current findings of the present study showed that the training designed and applied in the present study has proven to be reliable and valid. They indicated that the participants' writing skill has been enhanced $(p<0.0001)$. This means that the suggested instructional model of the textual metafunction has been effective in enhancing the levels of cohesion and coherence in the participants' writing tasks, since the mean difference was (1.93).

Furthermore, Bloor and Bloor (2004) believe, the students who are about to participate in the IELTS and other such exams can benefit from the use of the textual metafunction to approve their writing skill. In addition, the participants took part in the present research were completely satisfied with the results, and they found it useful to improve their writing skill.

The results of the present study provide empirical support for the significance of using the textual metafunction in the writing training courses. Therefore, the most significant pedagogical implication is that the 'writing' teachers can make a good use of the textual metafunction during their writing classes.

There are various analytical writing scales in which the cohesion or coherence has been allotted some scores to it (Weir 1990, Brown and Bailey: 1984) to name a few. However, there are less rating scales in which both 
cohesion and coherence have been considered (Hungarian School-Leaving English Examination Reform Project, 2001, as cited in Tankó, 2001). In fact, since discourse is created when both cohesion and coherence work together, it is necessary to develop the rating scales in which both cohesion and coherence have been considered together. Furthermore, since the textual metafunction is directly related to the creation of cohesion and coherence, it is possible to develop a rating scale for writing in which the textual metafunction is considered instead of cohesion and coherence. Moreover, the results showed that there is a strong need for applying the analytical writing scales, since these scales are able to cover almost all aspects of writing, and the teachers can provide much better feedbacks for their students through using such scales.

Besides the students and teachers, the writers could also benefit from the textual metafunction to produce more cohesive and coherent pieces of writing and to find more markets to sell their books. Moreover, since it is possible to analyze the levels of cohesion and coherence by using the textual metafunction, the Translation students can also benefit from this device, because it helps them to be the self-analyzers of their own translation projects. Furthermore, the Translation teachers also can use this device to evaluate the levels of cohesion and coherence in different texts, and choose the best ones to be translated by their students.

Based on the findings and conclusion of the present study, the researcher recommends the following:

1. Textual metafunction should have its place in the writing skill curriculum for English as a Foreign Language (EFL).

2. The 'ideational, and interpersonal' metafunctions are also required to be studied in the context of EFL writing skill.

3. More modern Writing scales are required to be developed, in which the cohesion and coherence are considered side by side, under the title of 'Discourse Analysis' (DA)

\section{References}

Aghagolzadeh, F., \& Farazandeh-pour, F. (2012). The Analysis of English-Persian Legal Translations Based on Systemic Functional Grammar Approach (SFG). Theory and Practice in Language Studies, 2(1), 126-131. http://dx.doi.org/10.4304/tpls.2.1

Ahour, T., \& Mukundan, J. (2009). Analytic Assessment of Writing: Diagnosing Areas of Strength and Weakness in the Writing of TESL Undergraduate Students. Iranian Journal of Language Studies (IJLS), 3(2), 195-208.

Aijmer, K., \& Stenström, A. B. (Eds.). (2004). Discourse Patterns in Spoken and Written Corpora. USA: John Benjamins Publishing.

Al-Hajaj, J. F., \& Davis, G. (Eds.). (2008). University of Basrah Studies in English Germany: Peter Lang.

Atlee, N. (1995). Advancing Writing Skills: A Guide to Authentic Writing. USA: Dandy Lion Publications.

Barkaoui, Kh. (2007). Rating scale impact on EFL essay marking: A mixed-method study. Assessing Writing, 12(2), 86-107. http://dx.doi.org/10.1016/j.asw.2007.07.001

Bickman, M. (1987). Active Learning in the University: An Inquiry into Inquiry. In Mary Ann Shea (Ed.), On Teaching, I, 31-61. Boulder, Colorado: University of Colorado.

Bloor, T., \& Bloor, M. (2004). The Functional Analysis of English: A Hallidayan Approach (2nd ed). London: Edward Arnold.

Breiter, C., \& Scardamalia, M. (1987). The psychology of written composition. Mahwah, NJ: Erlbaum.

Brown, J. D., \& Bailey, K. M. (1984). A categorical instrument for scoring second language writing skills. Language Learning, 34(4), 21-42. http://dx.doi.org/10.1111/j.1467-1770.1984.tb00350.x

Brown, K., \& Hood, S. (2003). Writing Matters: Writing Skills and Strategies for Students of English. UK: Cambridge University Press.

Bublitz, W., Lenk, U., \& Ventola, E. (Eds.). (1999). Coherence in Spoken and Written Discourse: How to Create It and How to Describe It. USA: John Benjamins Publishing Company.

Caffarel, A., Martin, J. R. Ch., \& Matthiessen M. I. M. (Eds.). (2004). Language Typology: A Functional Perspective. USA: John Benjamins Publishing Co.

Campos, M. A. J. L. E. (2010). Choosing A Good Scale to Evaluate Students' Writing. XXIV Panama TESOL Annual Congress 2010 (pp. 1-22).

Christie, F., \& Derewianka, B. (2010). School Discourse: Learning to Write Across the Years of Schooling. India: Continuum International Publishing Group. 
Cook, G. (1989). Discourse. In Candlin \& Widdowson (Eds). China: Oxford University Press.

Correa, D. M. (2008). Understanding Voice in the Disciplines: The Struggles of Latina Non-Traditional Students and Their Instructors. Unpublished doctoral dissertation, University of Massachusetts, Amherst.

Craig, J. L. (2013). Integrating Writing Strategies in EFL/ESL University Contexts: A Writing-Across-the-Curriculum Approach. New York: Routledge.

Dias, P., Freedman, A., Medway, P., \& Par, A. (2008). Worlds Apart: Acting and Writing in Academic and Workplace Contexts. USA: Taylor \& Francis e-Library.

Eftekhar Paziraie, M. (2012a). The Study of Language in the Oscar Cinematic Discourse: The Movie "A Separation": An Analysis of the Metafunctions in Nader and Simin's Dialogues. Germany: LAP Publishing.

Eftekhar Paziraie, M. (2012b). Postcolonial Discourse: An Analysis of the Literary Translation, A Discourse Analysis of the Postcolonial Novels and Their Translations at the Micro and Macro Levels. Germany: LAP Publishing.

Eggins, S. (2004). Introduction to Systemic Functional Linguistics (2nd Edition). Great Britain: MPG Books Ltd., Bodmin, Cornwall.

Enkvist, N. E. (1990). Seven Problems in the Study of Coherence and Interpretability. In U. Connor, \& A.M. Johns (Eds), Coherence in Writing Research and Pedagogical Perspectives (pp. 9-28). Alexanderia, VA: TESOL.

Flower, L., \& Hayes, J. R. (1980). The dynamics of composing: Making plans and juggling constraints. In L. Gregg, \& E. Steinberg (Eds.), Cognitive processes in writing (pp. 31-50). Hillsdale, NJ: L. Erlbaum.

Fries, P. H., \& Gregory, M. J. (Eds.). (1995). Discurse in Society: Systemic Functional Perspectives: Meaning and Choice in Language Studies for Michael Halliday. USA: Ablex Publishing Corporation.

Gernsbacher, M. A., \& Givón, T. (Eds.). (1995). Coherence in Spontaneous Text. USA: John Benjamins Publishing Company.

Ghadessy, M. (1995). Thematic Development of English Texts. Great Britain: Ewan Smith.

Grabe, W., \& Kaplan, W. (1996). Theory and practice of writing: An applied linguistic perspective. London: Longman.

Halliday, M. A. K. (1970). Language Structure and Language Function. In J. Lyons (Ed), New horizons in linguistics. London: Penguin.

Halliday, M. A. K., \& Hassan, R. (1976). Cohesion in English. London: Longmans.

Halliday, M. A. K. (1985). An Introduction to Functional Grammar. London: Edward Arnold.

Hawkey, R., \& Barker, F. (2004). Developing a Common Scale for the Assessment of Writing. Assessing Writing. 9(2), 122-159. http://dx.doi.org/10.1016/j.asw.2004.06.001

Hayes, J. R. (1996). A new framework for understanding cognition and affect in writing. In C. M. Levy, \& S. E. Ransdell (Eds.), The science of writing: Theories, methods, individual differences, and applications ( $\mathrm{pp}$. 1-27). Mahwah: New Jersey: Lawrence Erlbaum Associates.

Kellogg, R. T. (1996). A model of working memory in writing. In C. M. Levy, \& S. E. Ransdell (Eds.), The science of writing: Theories, methods, individual differences, and applications (pp. 57-71). Mahwah, NJ: Lawrence Erlbaum Associates, Inc.

Knoch, U. (2009). Diagnostic Writing Assessment: The Development and Validation of a Rating Scale. Germany: Peter Lang GmbH.

Kroll, B. (2008). Exploring the Dynamics of Second Language Writing. USA: Cambridge University Press.

Manchón, R. (Ed.). (2009). Writing in Foreign Language Contexts: Learning, Teaching, and Research. Great Britain: MPG Books Group.

Martin, James R. (1992). English Text: System and Structure. Amsterdam: John Benjamins.

Martin, B., \& Ringham, F. (2006). Key Terms in Semiotics. Great Britain: MPG Books Group.

Oller, J. W., \& Jonz. J. (1994). Cloze and Coherence. USA: Associated University Presses.

Rubio, D. S. M. M. (2007). English Discourse Markers of Reformulation. Germany: Peter Long AG, International Academic Publishers. 
Sandres, T., \& Maat, H. P. (2006). Cohesion and Coherence: Linguistic Approaches. Netherlands: Elsevier.

Shaw, S. D., \& Weir, C. J. (2007). Examining Writing: Research and Practice in Assessing Second Language Writing. UK: Cambridge University Press.

Speck, B. W., \& Greenwood, J. E. (1998). Grading Student Writing: An Annotated Bibliography. USA: Information Age Publishing.

Sum-hung, E. L. (2007). A Systemic Functional Grammar of Chinese. Great Britain: Cromwell Press, Trowbridge, Wiltshire.

Sundem, G. (2007). Improving Student Writing Skills. USA: Corinne Burton, M.A. Ed.

Taboada, M. T. (2004). Building Coherence And Cohesion: Task-Oriented Dialogue In English And Spanish. USA: John Benjamins Publishing Company.

Tankó, G. (2001). Into Europe, The Writing Handbook. In J. Charles Alderson (Ed.). Uk: British Council-Funded Project.

Tanskanen, S. K. (2006). Collaborating Towards Coherence: Lexical Cohesion in English Discourse. USA: John Benjamins Publishing Company.

Weir, C. J. (1990). Communicative Language Testing. NJ: Prentice Hall Regents.

Winter, E. D. (1977). A clausal-relation approach to English texts: a study of some predictive lexical items in written discourse. Instructional Science (special issue), 6, 1-92.

Zimmerman, R. (2000). L2 writing: Subprocesses, a model of formulating and empirical findings. Learning and instruction, 10, 73-99.

\section{Appendix}

Analytic Scoring Scale (taken from Hungarian School-Leaving English Examination Reform Project, 2001, as cited in Tankó, 2001).

\begin{tabular}{|c|c|c|c|c|}
\hline & Task achievement & $\begin{array}{l}\text { Coherence and } \\
\text { Cohesion }\end{array}$ & Grammar & Vocabulary \\
\hline \multirow[b]{2}{*}{7} & - all content points elaborated & - fully coherent text & - wide range of & - wide range of vocabulary \\
\hline & - meets text type requirements & $\begin{array}{l}\text { - cohesive on both } \\
\text { sentence and } \\
\text { paragraph level }\end{array}$ & $\begin{array}{l}\text { structures } \\
\text { - few inaccuracies } \\
\text { that do } \\
\text { not hinder/disrupt } \\
\text { communication }\end{array}$ & $\begin{array}{l}\text { accurate vocabulary } \\
\text { communicating clear ideas } \\
\text { - relevant to content }\end{array}$ \\
\hline \multicolumn{5}{|l|}{6} \\
\hline 5 & $\begin{array}{l}\text { - most content points } \\
\text { elaborated } \\
\text { - all content points mentioned } \\
\text { - some inconsistencies in text } \\
\text { type requirements }\end{array}$ & $\begin{array}{l}\text { - good } \\
\text { sentence-level } \\
\text { cohesion } \\
\text { paragraph-level } \\
\begin{array}{l}\text { pohe } \\
\text { coherence and } \\
\text { cohesion }\end{array}\end{array}$ & $\begin{array}{l}\text { - good range of } \\
\text { structures } \\
\text { inaccuracies } \\
\text { hinder /disrupt } \\
\text { communication }\end{array}$ & $\begin{array}{l}\text { - good range of vocabulary } \\
\text { - occasionally inaccurate } \\
\text { vocabulary } \\
\text { communicating mainly clear } \\
\text { ideas } \\
\text { - overall relevant to content }\end{array}$ \\
\hline \multicolumn{5}{|c|}{ 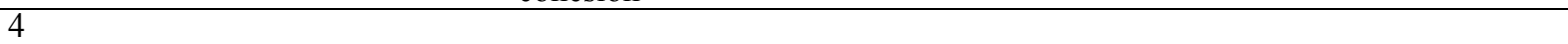 } \\
\hline 3 & $\begin{array}{l}\cdot \text { some content points } \\
\text { elaborated } \\
\text { - most content points } \\
\text { mentioned } \\
\text { - many inconsistencies in text } \\
\text { type requirements }\end{array}$ & $\begin{array}{lr} & \text { some } \\
\text { sentence-level } \\
\text { cohesion } \\
\text { - frequent lack of } \\
\text { paragraph level } \\
\text { coherence } \\
\text { cohesion }\end{array}$ & $\begin{array}{l}\text { - limited range of } \\
\text { structures frequent } \\
\text { inaccuracies } \\
\text { hinder/disrupt } \\
\text { communication }\end{array}$ & $\begin{array}{l}\text { - limited range of vocabulary } \\
\text { - frequently inaccurate } \\
\text { vocabulary } \\
\text { communicating some clear } \\
\text { ideas } \\
\text { - occasionally relevant to } \\
\text { content with some } \\
\text { chunks lifted from }\end{array}$ \\
\hline \multicolumn{5}{|l|}{2} \\
\hline 1 & $\begin{array}{l}\text { - no content point elaborated } \\
\text { - some content points } \\
\text { mentioned } \\
\text { - does not meet text type } \\
\text { requirements }\end{array}$ & $\begin{array}{l}\text { - lack of sentence- } \\
\text { and paragraph-level } \\
\text { cohesion } \\
\text { - text not coherent }\end{array}$ & $\begin{array}{l}\text { - no range of } \\
\text { structures } \\
\text { - mostly inaccurate }\end{array}$ & $\begin{array}{l}\text { - no range of vocabulary } \\
\text { - mostly inaccurate } \\
\text { vocabulary, communicating } \\
\text { few clear ideas } \\
\text { - mostly irrelevant to content } \\
\text { with several } \\
\text { chunks lifted from }\end{array}$ \\
\hline 0 & no assessable language & $\begin{array}{l}\text { no assessable } \\
\text { language }\end{array}$ & $\begin{array}{l}\text { no assessable } \\
\text { language }\end{array}$ & no assessable language \\
\hline
\end{tabular}

